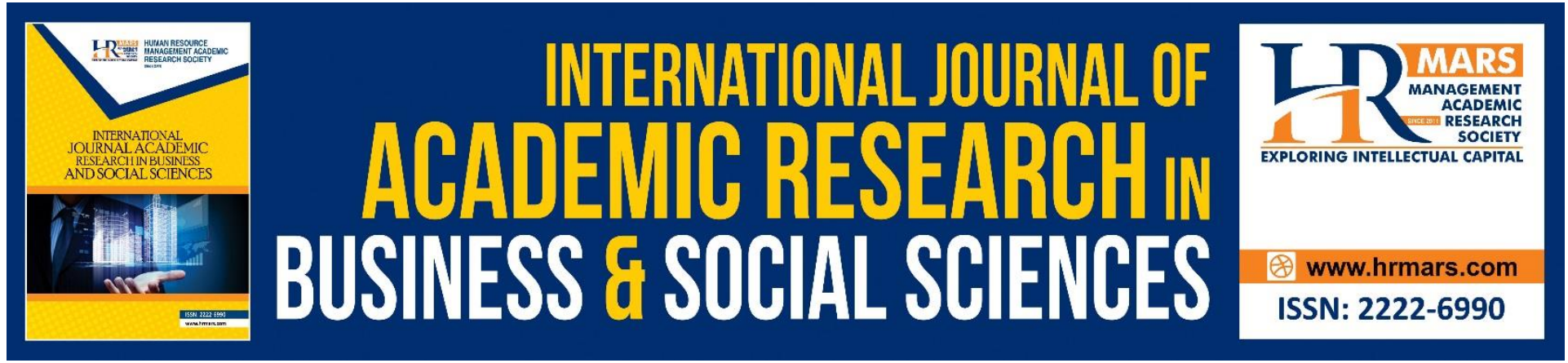

\title{
ESL Pre-Service Teachers' Evaluation of ESL Web Resources
}

\section{Noraini Said}

To Link this Article: http://dx.doi.org/10.6007/IJARBSS/v11-i6/10375

DOI:10.6007/IJARBSS/v11-i6/10375

Received: 17 April 2021, Revised: 18 May 2021, Accepted: 27 May 2021

Published Online: 22 June 2021

In-Text Citation: (Said, 2021)

To Cite this Article: Said, N. (2021). ESL Pre-Service Teachers' Evaluation of ESL Web Resources. International Journal of Academic Research in Business and Social Sciences, 11(6), 1563-1571.

Copyright: @ 2021 The Author(s)

Published by Human Resource Management Academic Research Society (www.hrmars.com)

This article is published under the Creative Commons Attribution (CC BY 4.0) license. Anyone may reproduce, distribute, translate and create derivative works of this article (for both commercial and non-commercial purposes), subject to full attribution to the original publication and authors. The full terms of this license may be seen at: http://creativecommons.org/licences/by/4.0/legalcode

Vol. 11, No. 6, 2021, Pg. 1563 - 1571

Full Terms \& Conditions of access and use can be found at http://hrmars.com/index.php/pages/detail/publication-ethics 


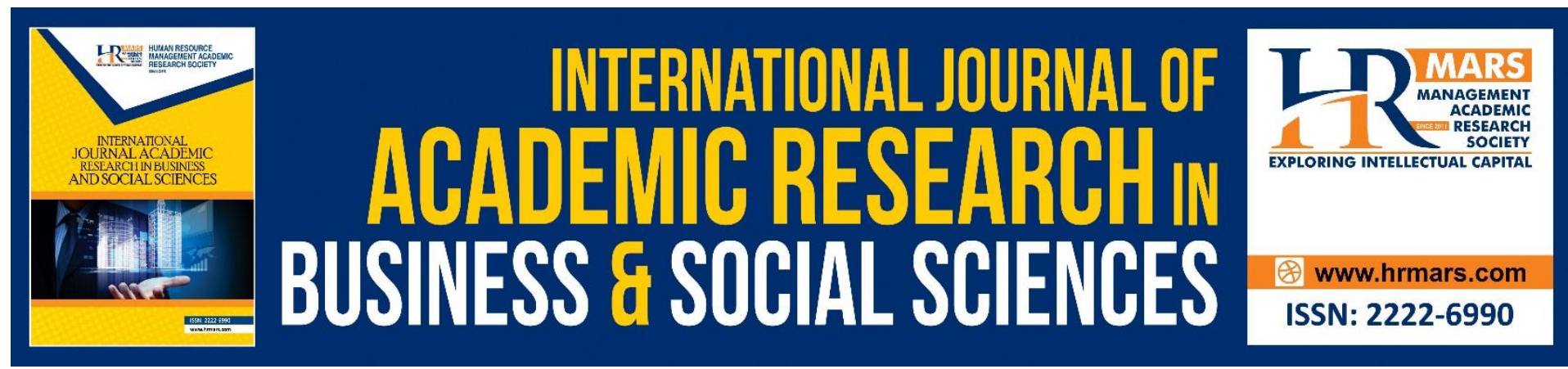

\title{
ESL Pre-Service Teachers' Evaluation of ESL Web Resources
}

\author{
Noraini Said \\ Universiti Malaysia Sabah \\ Email: Noraini.said@ums.edu.my
}

\begin{abstract}
There is an amazing proliferation of ESL online materials ready to be utilized by learners and instructors. Sadly, users are commonly overwhelmed by the immense volume and therefore must critically evaluate the ones which are useful for them. This study reports on ESL preservice teachers' evaluation of various ESL web-based resources for language learning and teaching in a Computer-Assisted Language Learning (CALL) course. 39 subjects participated in this study. Quantitative data was obtained from Son (2005) Language Learning Website Review Form which students completed, while video reviews and feedback forms produced by the students yielded qualitative data. $18 \mathrm{ESL}$ resources were evaluated based on 15 evaluation criteria. Findings show that in overall, most ESL resources were deemed useful for language teaching and learning. However, four evaluation criteria were frequently cited with low rating such as authority, feedback, multimedia and communication. 17 from $18 \mathrm{ESL}$ resources received high rating from the students. Video reviews validated data from students' evaluation forms. Findings further reinforce the need for teachers and students to critically evaluate resources for their language learning and teaching.
\end{abstract}

Keywords: ESL Web-Based Resources, Language Learning

\section{Introduction}

The proliferation of ESL online resources has been observed since the Internet boom in 1990s. Nowadays, such resources are available to cater to the different needs of users from all around the world. A search using Google on 11 $11^{\text {th }}$ March, 2021 alone yielded more than 96 million hits related to online ESL resources, and more than 112,000 hits on Google Scholar. This implies that there is a growing interest and demand in such resources as more and more online ESL resources are made available to interested users. Besides, such resources are also made as part of scholarly research and this proves how integral and essential these resources have become in education, especially in the ESL context.

These online ESL resources range from educational portals, online writing labs, online dictionaries, discussion boards, online forums and many more. The popularity of these resources are further increased by the explosion of web 2.0 technologies where online or internet resources are not just for display or just to be viewed only. Users can comment, interact, and sometimes edit the information on the web as well as sharing, discussing and inviting others to do the same. This has further elevated the status of Internet as a powerful 
resource in supporting education or information retrieval especially for ESL teachers and students.

As exciting as it may sound, as with other Internet resources, there is a great caution to using the Internet materials as references for educational or academic purpose. This is because, without having the skills and knowledge to filter unreliable information, the resources may not likely be helpful. Challenges and issues are often encountered in evaluating suitable resources such as the credibility and objectivity of the web authors, currency and accessibility of the web, and relevance and coverage of the content of the web.

Nonetheless, there are undoubtedly credible and reliable ESL resources such as the Purdue Online Writing Lab (http://owl.english.purdue.edu/), Internet TESL journal (http://iteslj.org), and the Electronic Journal of TESL (http://www.tesl-ej.org) which benefit ESL students and practitioners. But sadly enough, there is no guarantee that ESL students do make use of these helpful ESL resources. Instead, they may be using other resources available in the Internet. Therefore, it is necessary to evaluate the web sites with a critical approach (Kurt \& Emiroglu, 2018). ESL language teachers have to evaluate the resources not only for their teaching, but also for their learners.

Recent studies illustrate the need to evaluate websites in the teaching and learning of languages. For instance, Hossain et al. (2019) evaluates various effective web-based resources to emphasize the importance of ESL (English as a Second Language) learning and teaching. Son (2005) developed a 15-item website review form specifically for language learning. Another study by Aguayo \& Ramírez (2020) stressed the importance of web evaluation especially with functionality and usability tests to identify the strengths and weaknesses of the language learning website. Their study reviewed four renowned websites from the LinguApp corpus: ESOL-Courses, BBC, British Council and Cambridge English 2. Therefore, the current study aims to evaluate eighteen ESL web resources based on the stipulated evaluation criteria in order to equip the ESL pre-service teachers with the critical evaluations skills for ESL teaching and learning context.

Research questions:

1. What is ESL pre-service teachers' evaluation of $18 \mathrm{ESL}$ web resources based on Son's Language Learning Website Review (2005)?

2. How do ESL pre-service teachers view the $18 \mathrm{ESL}$ web resources based on the content, and usefulness of the sites?

\section{Methodology}

39 pre-service teachers enrolled in the course "ICT in English Language Teaching" were involved in this study. The course aims to equip pre-service teachers with critical skills and knowlege related to the application of ICT in teaching and learning. 21 sites were selected by the instructor, and each site was designated to three to five reviewers. All participants are between the ages of 22 and 24, and are very comfortable using a computer and the web. None of the participants was familiar with the sites to be evaluated. They were given time to evaluate the sites using Son (2005) Language Learning Website Review Form, and prepare a 3-5 minute video review on the selected site. An open-ended feedback form was also given to record any problems or errors that they encountered during the exploration. The data were collected using Son (2005) Language Learning Website Review Form which is a 15-item measuring users' agreement using 5-point Likert scale, a feedback form and students' video reviews focusing on the usability aspects such as content, and usefulness of the sites. Thematic content analysis was used for qualitative data to capture the emergent themes from 
the video reviews and the qualitative feedback form. Data obtained from the review form were quantitatively analyzed using descriptive statistics.

\section{Results/ Findings}

What is the ESL pre-service teachers' evaluation of the ESL web resources based on Son's Language Learning Website Review (2005)?

Table 1.0 presents students' evaluation of the $18 \mathrm{ESL}$ web resources based on fifteen criteria in the questionnaire. The web resources are ordered from the highest mean values to the lowest mean values.

Table 1.0: ESL Web Resources Evaluation by ESL Pre-service Teachers

\begin{tabular}{|c|c|c|c|c|c|c|c|c|c|c|}
\hline Evaluation & $\begin{array}{c}\text { Site } \\
1\end{array}$ & $\begin{array}{l}\text { Site } \\
2\end{array}$ & $\begin{array}{c}\text { Site } \\
3\end{array}$ & $\begin{array}{c}\text { Site } \\
4\end{array}$ & $\begin{array}{c}\text { Site } \\
5\end{array}$ & $\begin{array}{l}\text { Site } \\
6\end{array}$ & $\begin{array}{l}\text { Site } \\
7\end{array}$ & $\begin{array}{l}\text { Site } \\
8\end{array}$ & $\begin{array}{c}\text { Site } \\
9\end{array}$ & Site 10 \\
\hline Purpose & 5.00 & 5.00 & 5.00 & 5.00 & 5.00 & 4.50 & 5.00 & 4.50 & 5.00 & 5.00 \\
\hline Accuracy & 5.00 & 5.00 & 4.50 & 4.50 & 4.00 & 5.00 & 4.33 & 5.00 & 5.00 & 4.50 \\
\hline Currency & 5.00 & 5.00 & 5.00 & 4.00 & 4.00 & 5.00 & 4.33 & 5.00 & 3.50 & 4.00 \\
\hline Authority & 4.50 & 1.50 & 4.00 & 4.00 & 4.00 & 4.50 & 4.00 & 3.00 & 4.50 & 3.50 \\
\hline $\begin{array}{l}\text { Loading } \\
\text { Speed }\end{array}$ & 5.00 & 5.00 & 5.00 & 4.50 & 5.00 & 5.00 & 4.67 & 4.50 & 4.50 & 4.50 \\
\hline Usefulness & 5.00 & 5.00 & 4.50 & 4.50 & 5.00 & 4.50 & 5.00 & 5.00 & 4.50 & 5.00 \\
\hline $\begin{array}{l}\text { Organizati } \\
\text { on }\end{array}$ & 5.00 & 5.00 & 5.00 & 5.00 & 5.00 & 5.00 & 4.33 & 4.50 & 4.50 & 4.50 \\
\hline Navigation & 5.00 & 5.00 & 5.00 & 5.00 & 5.00 & 4.00 & 4.00 & 5.00 & 5.00 & 3.00 \\
\hline Reliability & 4.50 & 5.00 & 5.00 & 5.00 & 5.00 & 5.00 & 4.00 & 4.50 & 4.00 & 5.00 \\
\hline $\begin{array}{l}\text { Authentici } \\
\text { ty }\end{array}$ & 5.00 & 5.00 & 4.00 & 5.00 & 5.00 & 4.00 & 4.33 & 4.00 & 4.50 & 4.50 \\
\hline $\begin{array}{l}\text { Interactivi } \\
\text { ty }\end{array}$ & 5.00 & 5.00 & 4.50 & 5.00 & 5.00 & 4.00 & 4.67 & 4.00 & 4.00 & 4.50 \\
\hline Feedback & 4.00 & 5.00 & 4.50 & 4.00 & 4.00 & 4.00 & 4.67 & 4.00 & 4.50 & 3.50 \\
\hline $\begin{array}{l}\text { Multimedi } \\
\text { a }\end{array}$ & 5.00 & 5.00 & 5.00 & 5.00 & 4.00 & 3.00 & 4.33 & 4.00 & 3.50 & 4.00 \\
\hline $\begin{array}{l}\text { Communic } \\
\text { ation }\end{array}$ & 5.00 & 5.00 & 5.00 & 3.50 & 2.00 & 4.00 & 3.33 & 3.50 & 2.00 & 3.00 \\
\hline $\begin{array}{l}\text { Integratio } \\
\mathrm{n}\end{array}$ & 5.00 & 5.00 & 4.50 & 4.00 & 3.50 & 4.00 & 4.33 & 4.50 & 4.00 & 4.50 \\
\hline $\begin{array}{l}\text { Total } \\
\text { Mean }\end{array}$ & 4.87 & 4.77 & 4.70 & 4.53 & 4.37 & 4.37 & 4.36 & 4.33 & 4.20 & 4.20 \\
\hline
\end{tabular}

Note: Site 1 (www.englishcentral.com), site 2 (www.englishclub.com), site 3 (www.engvid.com), site 4 (evaeaston.com), site 5 (owl.purdue.edu), site 6 (www.eslcafe.com), site 7 (esl-lab.com), site 8 (www.bbc.co.uk/learningenglish), site 9 (a4esl.org), site 10 (www.ereadingworksheets.com), 
Table 1.0 cont.

\begin{tabular}{|l|c|c|c|c|c|c|c|c|}
\hline \multicolumn{1}{|c|}{ Evaluation } & Site & Site & Site & $\begin{array}{c}\text { Site } \\
12\end{array}$ & $\begin{array}{c}\text { Site } \\
13\end{array}$ & $\begin{array}{c}\text { Site } \\
16\end{array}$ & $\begin{array}{c}\text { Site } \\
17\end{array}$ & $\begin{array}{c}\text { Site } \\
18\end{array}$ \\
\hline Purpose & 4.50 & 4.67 & 4.67 & 4.00 & 4.00 & 4.00 & 3.00 & 5.00 \\
\hline Accuracy & 4.00 & 5.00 & 4.33 & 4.50 & 5.00 & 4.00 & 4.50 & 4.00 \\
\hline Currency & 4.00 & 4.00 & 4.67 & 4.00 & 4.50 & 3.50 & 5.00 & 3.50 \\
\hline Authority & 3.00 & 4.00 & 4.00 & 3.50 & 2.50 & 3.50 & 3.50 & 2.50 \\
\hline $\begin{array}{l}\text { Loading } \\
\text { Speed }\end{array}$ & 3.00 & 4.67 & 4.00 & 5.00 & 4.50 & 4.00 & 4.00 & 3.00 \\
\hline Usefulness & 5.00 & 4.33 & 4.67 & 4.00 & 4.00 & 4.50 & 2.50 & 3.50 \\
\hline Organization & 4.50 & 4.67 & 4.33 & 4.00 & 3.50 & 3.00 & 4.00 & 3.50 \\
\hline Navigation & 4.50 & 4.33 & 4.33 & 4.00 & 4.50 & 4.00 & 3.50 & 2.50 \\
\hline Reliability & 4.00 & 4.67 & 3.00 & 3.50 & 4.00 & 3.00 & 2.50 & 2.50 \\
\hline Authenticity & 3.50 & 4.67 & 4.33 & 3.50 & 4.00 & 4.00 & 4.50 & 3.00 \\
\hline Interactivity & 4.00 & 3.00 & 3.67 & 4.00 & 4.00 & 4.00 & 2.50 & 2.50 \\
\hline Feedback & 4.00 & 2.33 & 3.00 & 3.50 & 2.50 & 4.00 & 2.50 & 2.50 \\
\hline Multimedia & 4.00 & 3.33 & 2.67 & 4.00 & 2.50 & 4.50 & 2.00 & 3.50 \\
\hline $\begin{array}{l}\text { Communicat } \\
\text { ion }\end{array}$ & 4.00 & 1.67 & 3.67 & 3.00 & 4.00 & 2.50 & 2.50 & 2.50 \\
\hline Integration & 4.50 & 4.33 & 4.00 & 3.50 & 3.00 & 4.00 & 3.00 & 2.00 \\
\hline Total Mean & 4.03 & 3.98 & 3.96 & 3.87 & 3.77 & 3.77 & 3.30 & 3.07 \\
\hline
\end{tabular}

Note: Site 11 (writeandimprove.com), site 12 (esl-bits.net), site 13 (www.dailygrammar.com), site 14 (manythings.com), site 15 (englishpage.com), site 16 (englishmedialab.com), site 17 (www.ef.com/wwen), site 18 (www.englishmaven.org/Pages)

All participants generally agreed that the content of the ESL web resources sites was accurate and the purpose was made clear although there were some differences in the degree of their satisfaction. 4 websites have low mean for 'Authority' which could affect the site's total mean. Higher mean values for almost all evaluation criteria were observed for Site 1 up to Site 11. Lower evaluation is observed for the last 7 websites. Overall, six web sites were rated as "Good-Appropriate for use" (between 3.1 and 4.0) while 11 Web sites (i.e., Site 1 to 11) were rated as 'Excellent-Highly recommended" (between 4.1 to 5.0). Only 1 website is rated as 'Adequate- Acceptable with reservation'. 
Table 2.0: Overall Mean Values based on Evaluation Criteria.

\begin{tabular}{|l|c|c|}
\hline Evaluation Criteria & Mean & SD \\
\hline $\begin{array}{l}\text { Purpose: Is the purpose clear? Is the content in line with the } \\
\text { purpose? Is the website appropriate for its targeted learner?] }\end{array}$ & 4.57 & 0.53 \\
\hline $\begin{array}{l}\text { Accuracy: Is the content accurate? Are spelling and grammar } \\
\text { accurate?] }\end{array}$ & 4.54 & 0.41 \\
\hline Currency: Is the Website current? Is the Website updated regularly?] & 4.23 & 0.67 \\
\hline $\begin{array}{l}\text { Authority: Is there information on the author? Is the author well- } \\
\text { recognized for his or her work?] }\end{array}$ & 3.42 & 0.79 \\
\hline $\begin{array}{l}\text { Loading speed: Does the Website download fast? Do the content } \\
\text { pages download efficiently?] }\end{array}$ & 4.37 & 0.64 \\
\hline $\begin{array}{l}\text { Usefulness: Does the Website provide useful information? Are the } \\
\text { language activities or tasks useful?] }\end{array}$ & 4.51 & 0.62 \\
\hline $\begin{array}{l}\text { Organization: Is the Website well organised and presented? Is the } \\
\text { Website interesting to look at and explore? Are screen displays } \\
\text { effective?] }\end{array}$ & 4.39 & 0.59 \\
\hline $\begin{array}{l}\text { Navigation: Is the Website easy to navigate? Are on-screen } \\
\text { instructions easy to follow? Is it easy to retrieve information? Are } \\
\text { hyperlinks given properly?] }\end{array}$ & 4.37 & 0.71 \\
\hline $\begin{array}{l}\text { Reliability: Is the Website free of bugs and breaks? Is the Website } \\
\text { free of dead links?] }\end{array}$ & 4.20 & 0.83 \\
\hline $\begin{array}{l}\text { Authenticity: Are the learning materials authentic? Are authentic } \\
\text { materials provided in appropriate contexts?] }\end{array}$ & 4.20 & 0.55 \\
\hline $\begin{array}{l}\text { Interactivity: Is the Website interactive? Are methods for user input } \\
\text { effectively employed?] }\end{array}$ & 4.07 & 0.75 \\
\hline $\begin{array}{l}\text { Feedback: Is feedback on learner responses encouraging? Is error } \\
\text { handling meaningful and helpful?] }\end{array}$ & 3.68 & 0.79 \\
\hline $\begin{array}{l}\text { Multimedia: Does the Website make effective use of graphics, sound } \\
\text { and colour? Is the level of audio quality, the scale of graphics or } \\
\text { video display appropriate for language learning?] }\end{array}$ & 3.70 & 0.93 \\
\hline $\begin{array}{l}\text { Communication: Can the user communicate with real people on-line } \\
\text { through the Web site? Is on-line help available?] }\end{array}$ & 3.10 & 1.17 \\
\hline $\begin{array}{l}\text { Integration: Can the learning materials be integrated into a } \\
\text { curriculum? Does the content fit with curricular goals?] }\end{array}$ & 0.73 \\
\hline
\end{tabular}

Table 2.0 indicates the overall mean of all 18 evaluated websites based on the fifteen criteria. High mean values can be seen for 11 criteria; purpose, accuracy, usefulness, organization, navigation, loading speed, currency, reliability, authenticity and integration. The lowest mean value is recorded for Communication. Based on the video reviews and feedback form, participants expressed that since most of the websites have been around for quite some time, some websites are still 'assuming' the static webpages which do not allow optimum communication among users. There are 3 websites which offer great communication such as Site 1, Site 2 and Site 3. Overall, the eighteen web resources reviewed during the study serves as good resources for language teaching and learning. 


\section{How do ESL pre-service teachers view the $18 \mathrm{ESL}$ web resources based on the content and usefulness of the sites?}

Qualitative data gleaned from the 39 video reviews and the feedback form to answer this question. Many positive reviews were obtained as the following:

\section{URL: Englishclub.com}

In my honest opinion, this is my very first time visiting this site and I am totally in awe of content provided. It basically covers all the language activities like listening, speaking, reading, writing, grammar, vocabulary, pronunciation and forums. It has many fun and interesting ESL games and quizzes. User can ask help from the people from the site regarding your doubt about English.

\section{URL: Esl-bits.net}

Overall the site is very interesting and helpful. It comes with reading, listening, grammar and vocabulary sections where learners can pick which one they want to explore. The materials/content presented are very attractive. All the buttons and instructions are easy to understand.

\section{URL: Esl-lab.com}

This site in an application which can helps students to improve their listening skills. In this websites, there are difference type of audios are prepared for learners to learn by their own. Besides that, there are also questions provided while you are listening to the audio.

\section{URL: Englishmedialab.com}

English Media Lab offers Grammar, Vocabulary, Pronunciation, Exercises, Videos and Games for different levels, but mostly for elementary kids or beginners. However, it is quite confusing due to the pop-up advertisements such as games or links which may take us outside of the website. Overall, this website is quite interesting with different types of multimedia used in teaching English and also varieties of exercises which enhance student's language skills.

This site is pretty interesting for me because they conduct many games to study English and practice grammar, etc. The web is so easy to access. The web also provided the menu in colorful way so it engages people to come and access the web. The web is providing the game based on the level, that's why I think this web is suitable to many people in various age.

\section{URL: writeandimprove.com}

This site is really amazing as you can use it for free. Moreover, it helps you to improve your writing skills. As you enter the site, you will be given level option to choose. You can enter in which level you are and started to answer the task given. After you submitted it, only few seconds you will get the feedback. From there, you can evaluate your writing skills. 


\section{URL: avaeaston.com}

Eva Easton's is a website that teach the American English Pronunciation for free. Basically it focus more towards speaking and listening skills. It teach learners how to pronounce word with the final -ed, $-s$, how to pronounce linking words, the stress patterns, consonants and vowels. After each lesson, it will give out quiz so that learner can evaluate their own strengths and weaknesses.

\section{URL: owl.purdue.edu}

Purdue University is an online site which provides undergraduates with valuable pointers on how to efficiently write a proper academic essay. Apart from pointers, undergraduates who wish to check their essays for any plagiarism can also do it at this site. And for those who wish to strengthen their writing skills can do it with the exercises that Purdue University has in store.

One participant was quite critical in his evaluation by commenting on the functionality issues and Son (2005) evaluation criteria (currency, interactivity) such as the following:

\section{URL: Eslcafe.com}

The site uses an appropriate amount of learning materials and uses the multimedia features in a way that does not overwhelm learners. However, there is no use of videos and lack interactive activities. Information is neatly organized, however live help from tutors are not available and it is uncertain whether the author updates regularly.

Participants' positive reviews indicate their preference and agreement of the use of the evaluated websites as ESL web resources. Results also indicate that participants' evaluation of the websites using Son's instrument (2005) and their qualitative findings are closely related. Apart from the positive reviews, there were some issues raised by the participants such as their dissatisfaction with pop-up advertisements (5 mentions), difficulty to locate author information in the site ( 3 mentions), and the lack of platform to communicate (1 mention). Nevertheless, these issues seemed not to affect participants' overall impression of the $18 \mathrm{ESL}$ web resources.

\section{Conclusion}

This study evaluated eighteen ESL web resources based on Son (2005) Language Learning Website Review Form, video reviews and a feedback form. In this paper, the evaluation of the sites was made from the students' point of view. The main findings of the evaluation of the ESL web resources were that (1) 11 websites are highly recommended for use (teaching and learning) (2) the content and usefulness of the sites were evaluated as very relevant to the sites main purposes. Further, the sites were perceived as beneficial to participants as prospective language teachers, and language learners at the same time. The participants were also able to apply their skills in evaluating the various ESL web resources which will be handy in their future career. 


\section{References}

Aguayo, N., \& Ramírez, C. M. (2020). Does technical assessment matter? Functionality and usability testing of websites for ESL/EFL autonomous learners. Research in Learning Technology, 28(1063519), 1-26. https://doi.org/10.25304/rlt.v28.2353

Hossain, M. A., Begum, M. K., \& Rahman, A. F. M. M. (2019). Use of E-Sources for Esl Teaching and Learning. 2(1), 79-84.

Kurt, A. A., \& Emiroglu, B. G. (2018). Analysis of Students' Online Information Searching Strategies, Exposure to Internet Information Pollution and Cognitive Absorption Levels Based on Various Variables. Malaysian Online Journal of Educational Technology, 6(1), 18-29. www.mojet.net

Son, J. (2005). Exploring and Evaluating Language Learning Web Sites. In Enhancing learning and teaching: Pedagogy, technology and language. (Vol. 31, Issue 4, p. 17). Post Pressed. https://doi.org/10.1108/sr.2011.08731daa.016 